\title{
PTPN6 wt Allele
}

National Cancer Institute

\section{Source}

National Cancer Institute. PTPN6 wt Allele. NCI Thesaurus. Code C49526.

Human PTPN6 wild-type allele is located within 12p13 and is approximately $29 \mathrm{~kb}$ in length. This allele, which encodes tyrosine-protein phosphatase non-receptor type 6 protein, is involved in the dephosphorylation of protein-tyrosine phosphates. Aberrant methylation of the PTPN6 gene results in low expression levels in leukemias and lymphomas. 